\title{
Dynamic and Permissive Roles of TRPV1 and TRPV4 Channels for Thermosensation in Mouse Supraoptic Magnocellular Neurosecretory Neurons
}

\author{
Jessica R. Sudbury and Charles W. Bourque \\ Centre for Research in Neuroscience, Research Institute of the McGill University Health Centre, Montreal, Quebec, Canada
}

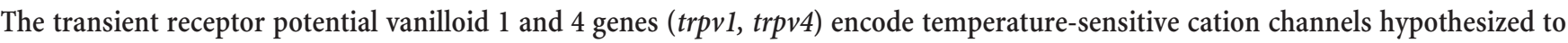
mediate thermoresponses in mammalian cells. Although such channels were shown to participate in the peripheral detection of ambient temperature, the specific roles of these channels in central thermosensory neurons remain unclear. Here we report that the membrane potential and excitability of mouse magnocellular neurosecretory cells (MNCs) maintained at physiological temperature were lowered in an additive manner upon pharmacological blockade, or genetic deletion, of trpv1 and trpv4. However extracellular recordings from spontaneously active MNCs in situ showed that blockade or genetic deletion of trpv 4 does not interfere with thermally induced changes in action potential firing, whereas loss of trpv1 abolished this phenotype. These findings indicate that channels encoded by trpv4 play a permissive role that contributes to basal electrical activity, but that trpv1 plays a dynamic role that is required for physiological thermosensation by MNCs.
\end{abstract}

\section{Introduction}

Thermosensitive neurons convert physiologically relevant changes in core body temperature $\left(\mathrm{Tb} ; 35-40^{\circ} \mathrm{C}\right)$ into significant changes in action potential frequency to mediate homeostatic control of vital physiological parameters, such as Tb (Hammel, 1968; Cabanac, 1975; Boulant, 1998, 2000; Romanovsky, 2007) and blood osmolality (Sharif-Naeini et al., 2008a; Sudbury et al., 2010). Although progress has been made in our understanding of mechanisms by which peripheral neurons detect the wide range of ambient temperatures to which skin is exposed (Dhaka et al., 2006; Caterina, 2007), the mechanisms by which ion channels contribute to the central detection of small variations in $\mathrm{Tb}$ remain poorly understood.

Recent studies have suggested that members of the transient receptor potential vanilloid (TRPV) family of ion channels might contribute to this process (Caterina, 2007; Kauer and Gibson, 2009; Sudbury et al., 2010). Four of the six genes encoding mammalian TRPV channels (trpv1-4) form heat-activated channels when expressed in heterologous cells (Patapoutian et al., 2003;

\footnotetext{
Received March 10, 2013; revised Aug. 20, 2013; accepted Sept. 19, 2013.

Author contributions: C.W.B. designed research; J.R.S. performed research; J.R.S. analyzed data; J.R.S. and C.W.B. wrote the paper.

This work was supported by Canadian Institutes of Health Research Operating Grants MOP-9939 and MOP-82818 to C.W.B., who was also the recipient of a James McGill Research Chair. J.R.S. was the recipient of a Doctoral Award from the Canada Graduate Scholarships Program and a Returning Student Award from the Integrated Program in Neuroscience of McGill University. The Research Institute of the McGill University Health Center is supported by the Fonds de recherche du Québec-Santé. The authors thank Dr. Wolfgang Liedtke (Duke University Medical Centre) for supplying trpv4 knock-out mice.

The authors declare no competing financial interests.

Correspondence should be addressed to Dr. Charles W. Bourque, Division of Neurology L7-216, Montreal General Hospital, 1650 Cedar Avenue, Montreal, Quebec H3G 1A4, Canada. E-mail: charles.bourque@mcgill.ca.

DOI:10.1523/JNEUROSCI.1048-13.2013

Copyright $\odot 2013$ the authors $\quad 0270-6474 / 13 / 3317160-06 \$ 15.00 / 0$
}

Ramsey et al., 2006; Caterina, 2007). Two of these (trpv1, $\operatorname{trpv4})$ are expressed in several brain regions (Liedtke et al., 2000, 2003; Güler et al., 2002; Sharif Naeini et al., 2006; Hollis et al., 2008; Nedungadi et al., 2012) and have been hypothesized to mediate temperature-dependent changes in neuronal excitability in the Tb range (Shibasaki et al., 2007; Sharif-Naeini et al., 2008a; McGaraughty et al., 2009). Moreover, animals lacking $\operatorname{trp} v 1$ or $\operatorname{trp} v 4$ show deficits in thermoregulation and osmoregulation (Caterina et al., 2000; Davis et al., 2000; Todaka et al., 2004; Lee et al., 2005; Moqrich et al., 2005; Sharif Naeini et al., 2006, 2008a; Garami et al., 2011).

A previous study showed that TRPV4 channels can increase the excitability of cultured hippocampal CA1 neurons by promoting a depolarized resting membrane potential (RMP) at $37^{\circ} \mathrm{C}$ but not at $25^{\circ} \mathrm{C}$ (Shibasaki et al., 2007). However, hippocampal neurons are not recognized as physiological thermosensors because their spontaneous activity is affected by severe hyperthermia $\left(>40^{\circ} \mathrm{C}\right.$ ) (Kim and Connors, 2012) rather than mild heating within the normal Tb range (Vasilenko et al., 1989). These observations suggest that the influence of TRPV4 channels toward heat-induced changes in excitability may be saturated at $\mathrm{Tb}$; therefore, the contribution of these channels to physiological thermosensation remains unclear.

Previous work has shown that a central thermosensory mechanism mediates anticipatory vasopressin (antidiuretic hormone) secretion to defend the body against heat-induced dehydration (Forsling et al., 1976). Moreover, the electrical activity of vasopressin-releasing magnocellular neurosecretory cells (MNCs) isolated from the rat supraoptic nucleus is highly temperature-sensitive in the $\mathrm{Tb}$ range (Sharif-Naeini et al., 2008a; Sudbury et al., 2010). Although channels encoded by trpv1 mediate a temperature-sensitive inward current in MNCs, VP 
a
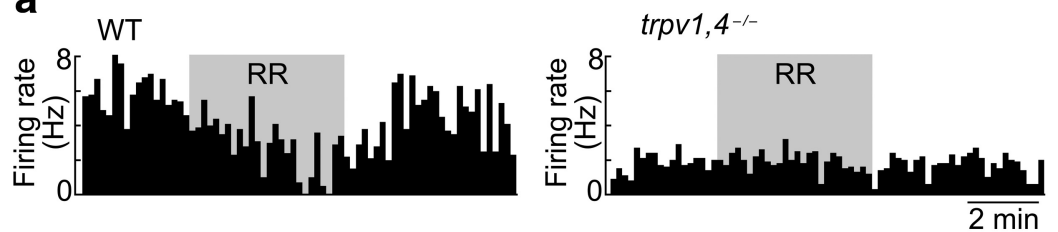

b
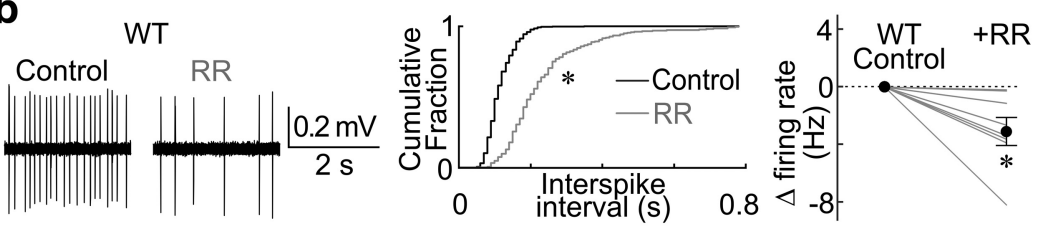

\section{C}
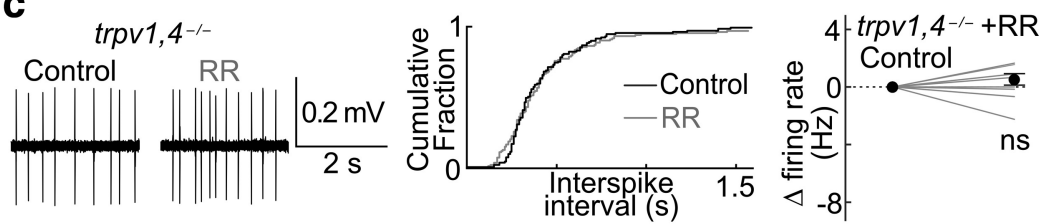

d
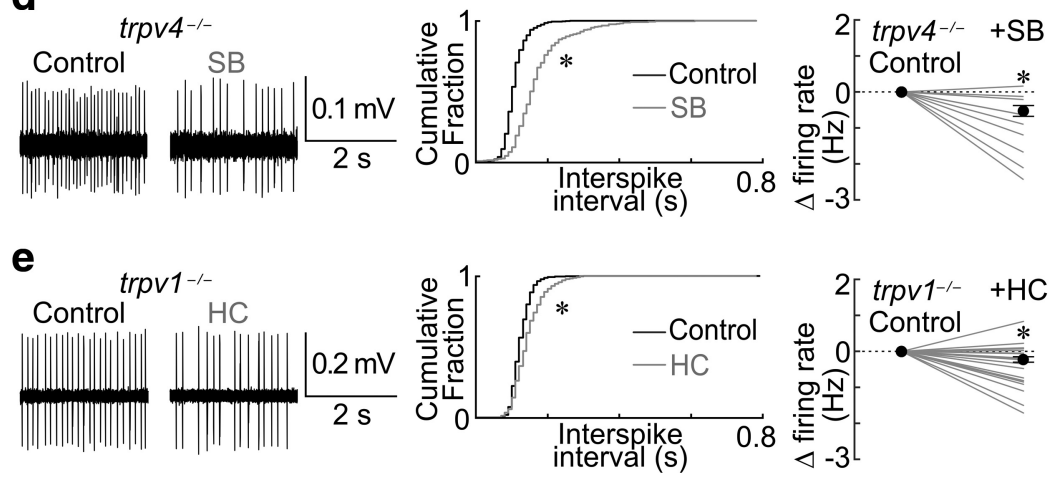

Figure 1. Spontaneous firing is sustained by TRPV1 and TRPV4 channels in supraoptic MNCs. $\boldsymbol{a}$, Spontaneous action potential firing recorded at Tb from a WT MNC was reversibly reduced during RR application (10 $\mu \mathrm{M}$, left), whereas firing of a trpv1,4 $4^{-1-}$ MNC during RR was unaffected (right; bin width $4 \mathrm{~s}$ ). $\boldsymbol{b}$ - $\boldsymbol{e}$, Left, MNC spontaneous firing recorded under control conditions (left) and during TRPV antagonism (right). Middle, Cumulative distribution of interspike intervals for cell shown at left. ${ }^{*} p<0.05$ (Komologrov-Smirnoff test). Line plots (right) represent normalized changes in spontaneous firing rate for all tested neurons; mean \pm SEM is overlaid. ${ }^{*} p<0.05$ (paired $t$ test). $\boldsymbol{b}$, Effects of RR on WT neuron firing. $\boldsymbol{c}$, Effects of RR on trpv1,4 ${ }^{-1-}$ neuron firing. ns, Not significant. $\boldsymbol{d}$, Effects of SB-366791 (SB, $3 \mu \mathrm{M}$ ) on trpv4 ${ }^{-1-}$ neuron firing. $\boldsymbol{e}$, Effects of HC-067047 (HC, $1 \mu \mathrm{M}$ ) on trpv $1^{-/-}$neuron firing. All tests were performed in the presence of kynurenic acid $(2 \mathrm{mM})$, bicuculline $(10 \mu \mathrm{M})$, and strychnine $(1 \mu \mathrm{M})$.

neurons have also been shown to specifically express trpv4 (Carreño et al., 2009; Nedungadi et al., 2012), and they display a persistent non-TRPV1 inward current that can be blocked by ruthenium red (RR) at temperatures $>35^{\circ} \mathrm{C}$ (Sharif-Naeini et al., 2008a). The objective of the present study was to determine whether TRPV4 channels contribute to heat detection in VP MNCs and to contrast the roles of TRPV1 and TRPV4 in thermosensation.

\section{Materials and Methods}

Animals. Experiments were performed in accordance with a protocol approved by the Animal Care Committee of McGill University. Adult male or female mice aged p21-28 (slices) or 2-6 months (explants) were from Charles River Laboratories (WT) or The Jackson Laboratory $\left(\operatorname{trpv} 1^{-1-}\right) \cdot \operatorname{trp} v 4^{-1-}$ animals bred in our colony (Liedtke and Friedman, 2003) were crossed with $\operatorname{trpv1} 1^{-1-}$ animals to generate $\operatorname{trpv1,4^{-1-}}$ mice.

Single-unit recording in hypothalamic explants. Hypothalamic explants (Sharif-Naeini et al., 2008b) were superfused at 1-2 $\mathrm{ml} / \mathrm{min}$ with carbogenated (95\% oxygen, $5 \% \mathrm{CO}_{2}$ ) artificial CSF (ACSF; $312 \pm 2 \mathrm{mosmol} /$ $\mathrm{kg}, \mathrm{pH}$ 7.2-7.3) comprising (in $\mathrm{mm}$ ) as follows: $128 \mathrm{NaCl}, 26 \mathrm{NaHCO}_{3}, 10$ D-glucose, $3 \mathrm{KCl}$, $1.25 \mathrm{NaH}_{2} \mathrm{PO}_{4}, 1.25 \mathrm{MgCl}_{2}$, and $2 \mathrm{CaCl}_{2}$. Extracellular recordings $(0.8-1.2 \mathrm{kHz})$ positioned within $50 \mu \mathrm{m}$ of the lateral aspect of the optic tract at the level of the middle cerebral artery were performed with glass microelectrodes $(10-20 \mathrm{M} \Omega$ ) filled with $1 \mathrm{M} \mathrm{NaCl}$. ACSF temperature was monitored via a thermocouple (IT-24P, Physitemp Instruments) within $\sim 1 \mathrm{~mm}$ of the cell recorded. Temperature was controlled using a TC-324B and SH-27B inline heater (Harvard Apparatus). Neurons with unstable baseline activity were discarded.

Whole-cell recording in hypothalamic slices. Acute angled hypothalamic slices $(300 \mu \mathrm{m}$ thick) (Trudel and Bourque, 2003; SharifNaeini et al., 2008b) were sectioned in ice-cold, carbogenated ( $95 \%$ oxygen, $5 \% \mathrm{CO}_{2}$ ) slicing solution (345 $\pm 5 \mathrm{mosmol} / \mathrm{kg}$ ) containing (in $\mathrm{mm}$ ) as follows: $87 \mathrm{NaCl}, 25 \mathrm{NaHCO}_{3}, 25$ D-glucose, 75 sucrose, $2.5 \mathrm{KCl}, \quad 1.25$ $\mathrm{NaH}_{2} \mathrm{PO}_{4} \cdot \mathrm{H}_{2} \mathrm{O}$, and $7 \mathrm{MgCl}_{2} \cdot 6 \mathrm{H}_{2} \mathrm{O}$, using a VT1200 vibrating blade microtome (Leica Microsystems) and incubated in the same solution at $32^{\circ} \mathrm{C}$ for $>45 \mathrm{~min}$. For recording, slices were transferred to a glass-bottomed recording chamber mounted on an Olympus BX-51WI microscope where they were superfused $(2.5$ $\mathrm{ml} / \mathrm{min}$ ) with carbogenated ( $95 \%$ oxygen, $5 \%$ $\mathrm{CO}_{2}$ ) ACSF. Recordings from visually identified SON MNCs (Sharif-Naeini et al., 2008b) were made using glass pipettes (3-5 M $\Omega$ ) filled with (in $\mathrm{mM}$ ) as follows: $130 \mathrm{~K}^{+}$gluconate, 10 HEPES, $1 \mathrm{MgCl}_{2}$, and 1 EGTA, adjusted to $290 \pm 2 \mathrm{mosmol} / \mathrm{kg}$ with mannitol $(\mathrm{pH} 7.2$ 7.3). Membrane resistance was measured as the slope of a line fitted through a minimum of 4 points in the linear range of the voltage-current plot. Cells exhibiting resistances $<500 \mathrm{M} \Omega$ were excluded.

Statistical analysis. All values are reported as mean \pm SEM. Statistical comparisons were made as appropriate using either Student's $t$ test, paired $t$ test, or a one-way ANOVA with the Student-Newman-Keuls post hoc analysis of significance (Sigma Plot 12.3 software; Systat Software). Cumulative distributions were compared with the Komologrov-Smirnoff test using Clampfit 10.2 software (Molecular Devices). Comparison of the slopes of linear regressions was performed using Prism version 5.01 software (GraphPad Software).

\section{Results}

\section{$\operatorname{Trpv} 1$ and $\operatorname{trpv} 4$ drive spontaneous firing at $\mathrm{Tb}$}

We first determined whether TRPV1 and TRPV4 channels participate in the maintenance of spontaneous activity at temperatures near the low range of $\mathrm{Tb}\left(34-36^{\circ} \mathrm{C}\right)$ using noninvasive single-unit extracellular recordings from MNCs in superfused explants of WT mouse hypothalamus. All recordings were made in the caudal part of the supraoptic nucleus, a region that is almost exclusively comprised of VP MNCs in mice (SharifNaeini et al., 2008b). Bath application of the nonspecific TRPV channel blocker RR $(10 \mu \mathrm{M})$ caused a significant and reversible reduction in firing rate (from $9.81 \pm 1.26 \mathrm{~Hz}$ to $6.76 \pm 1.70 \mathrm{~Hz}$; $n=9 ; p=0.0079$; Fig. 1a,b), suggesting that RR-sensitive ion channels contribute a sustained depolarizing current in MNCs at $34-36^{\circ} \mathrm{C}$. When repeated in explants prepared from mice lacking 

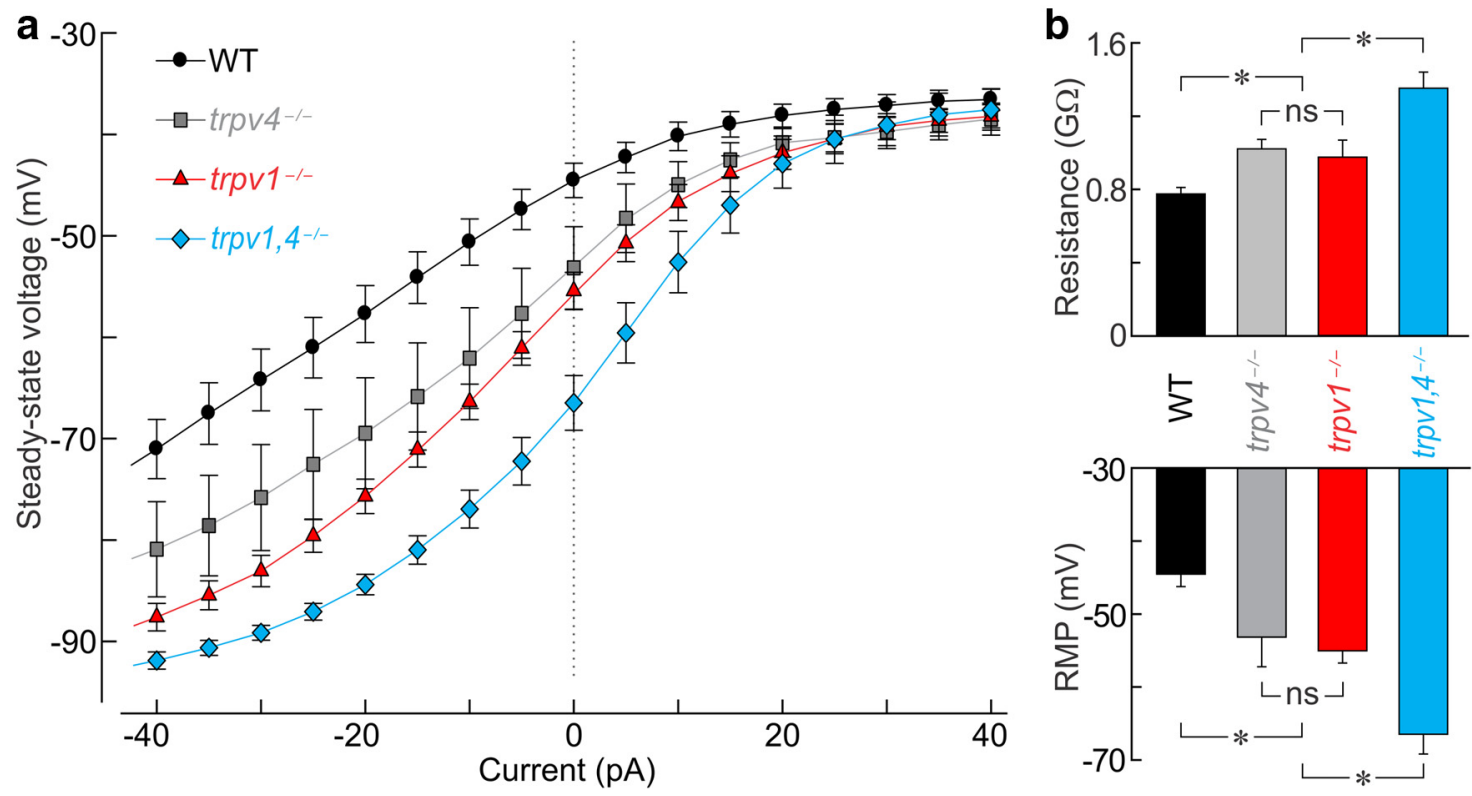

Figure 2. MNCs lacking TRPV channels are hyperpolarized at Tb. $a$, Plots represent mean \pm SEM steady-state voltage responses to current injection in WT, trpv4 ${ }^{-1-}$, trpv $1^{-1-}$, or trpv1, $4^{-1-}$ neurons. Voltage observed at zero current (dashed line) indicates RMP. $\boldsymbol{b}$, Error bars indicate mean \pm SEM values of membrane resistance (top) and RMP (bottom) in all genotypes. ${ }^{*} p<0.05$ (one-way ANOVA). ns, Not significantly different.

the expression of both $\operatorname{trpv1}$ and $\operatorname{trpv} 4$ genes $\left(\operatorname{trp} v 1,4^{-1-}\right.$ mice),

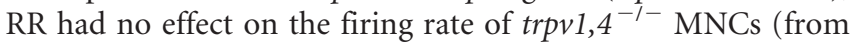
$10.06 \pm 3.03 \mathrm{~Hz}$ to $10.13 \pm 3.10 \mathrm{~Hz} ; n=8 ; p=0.442$; Fig. $1 a, c)$.

We next examined the effects of the specific TRPV1 channel antagonist SB-366791 (3 $\mu \mathrm{M})$ (Sharif-Naeini et al., 2008a) on MNCs recorded in $\operatorname{trp} v 4^{-1-}$ explants. As shown in Figure $1 d$, spontaneous firing was significantly reduced by the drug (from $7.83 \pm 2.10$ to $6.53 \pm 2.00 \mathrm{~Hz}, n=10, p=0.003)$. Moreover, spontaneous firing in explants prepared from mice lacking trpv1 expression $\left(\operatorname{trpv1^{-/-}}\right)$ was significantly reduced by the specific TRPV4 channel antagonist HC-067047 (1 $\mu \mathrm{M}$; Fig. 1e) (Everaerts et al., 2010), from $6.61 \pm 1.02 \mathrm{~Hz}$ to $6.08 \pm 1.06 \mathrm{~Hz}(n=17, p=$ 0.005). Together, these results suggest that TRPV1 and TRPV4 channels both actively contribute to the spontaneous action potential discharge in MNCs at physiological temperatures in situ.

\section{Trpv1 and trpv4 depolarize RMP and enhance excitability} at $37^{\circ} \mathrm{C}$

To determine whether the excitatory influence of TRPV1 and TRPV4 channels on MNCs can be attributed to an effect on the RMP of MNCs, we performed whole-cell recordings in acute hypothalamic slices prepared from WT, $\operatorname{trp} v 1^{-/-}, \operatorname{trp} v 4^{-\prime-}$, and $\operatorname{trp} v 1,4^{-1-}$ mice maintained in vitro at $37^{\circ} \mathrm{C}$. Steady-state voltage-current analysis revealed significant differences in the mean RMP of MNCs in the different genotypes. The RMP of MNCs lacking TRPV1 $(-55.43 \pm 1.84 \mathrm{mV} ; n=15)$ or TRPV4 $(-53.15 \pm 4.06 \mathrm{mV} ; n=9)$ was significantly more negative than that of WT neurons $(-44.53 \pm 1.70 \mathrm{mV} ; n=29 ; p<0.05$; Fig. $2 a, b)$. Moreover, the mean RMP of MNCs recorded from

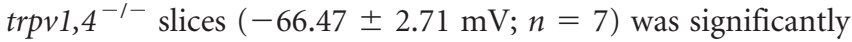
more hyperpolarized than all other genotypes $(p<0.05)$. Mean membrane input resistance was significantly greater in cells recorded from all three types of knock-outs compared with WT $(0.78 \pm 0.036 \mathrm{G} \Omega ; n=29 ; p<0.05$; Fig. $2 b)$. Although no difference was found between $\operatorname{trpv1} 1^{-1-}$ and $\operatorname{trp} v 4^{-1-}$ MNCs (1.02 $\pm 0.052 \mathrm{G} \Omega ; n=15 ; 0.98 \pm 0.093 \mathrm{G} \Omega ; p=0.616)$, cells

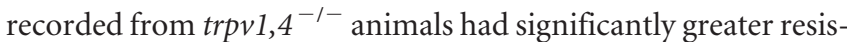
tance than all other groups $(1.35 \pm 0.088 \mathrm{G} \Omega ; n=7 ; p<0.05)$.

We next determined whether the negative RMPs associated with gene deletion were accompanied by decreases in excitability at $37^{\circ} \mathrm{C}$. Analysis of changes in action potential firing during steady-state current injection revealed no statistically significant difference in the mean values of rheobase $(-44.74 \pm 0.47 \mathrm{mV}$; $n=60 ; p=0.154$; Fig. $3 a)$ and maximal firing rate $(p=0.464$; $40.3 \pm 1.3 \mathrm{~Hz} ; n=23$; Fig. $3 b$ ) across genotypes. Differences in excitability were then examined using steady-state frequencycurrent (F-I) analysis. Because WT MNCs displayed spontaneous action potential firing in the absence of holding current $\left(\mathrm{I}_{\text {hold }}\right)$, a standard amount of negative $\mathrm{I}_{\text {hold }}(-50 \mathrm{pA})$ was applied to silence all cells at the beginning of the F-I protocol. As illustrated in Figure $3 c, d$, a significantly greater amount of current was required to achieve rheobase and elicit spiking in knock-out MNCs compared with WT neurons $(p<0.05)$. In agreement with this observation, MNCs from knock-out animals exhibited rightwardshifted F-I relations compared with WT MNCs (Fig. 2e), and cells


least excitable.

\section{TRPV4 channels are not required for dynamic thermosensing} near $\mathrm{Tb}$

To determine whether TRPV1 and TRPV4 channels both contribute to dynamic thermosensing in the physiological range, we examined the effect of a staircase thermal stimulus spanning $36-39^{\circ} \mathrm{C}$ in explants prepared from WT, $\operatorname{trp} v 1^{-1-}$, and $\operatorname{trp} v 4^{-1-}$ mice. As illustrated in Figure $4 a-c$, firing rates in WT MNCs were linearly related to temperature with a mean thermosensitivity coefficient $\left(\mathrm{T}_{\mathrm{C}}\right)$ of $1.28 \pm 0.13 \mathrm{~Hz} /{ }^{\circ} \mathrm{C}\left(r^{2}=\right.$ $0.4388 ; n=33 ; p<0.05)$. Dynamic steady-state thermosensing near $\mathrm{Tb}$ was significantly reduced in MNCs from trpv $1^{-1-}$ animals $\left(\mathrm{T}_{\mathrm{C}}=0.23 \pm 0.07 \mathrm{~Hz} /{ }^{\circ} \mathrm{C} ; n=23 ; p<0.0001\right.$ vs WT; Fig. $4 c$ ). In contrast, the mean $\mathrm{T}_{\mathrm{C}}$ observed for MNCs from 

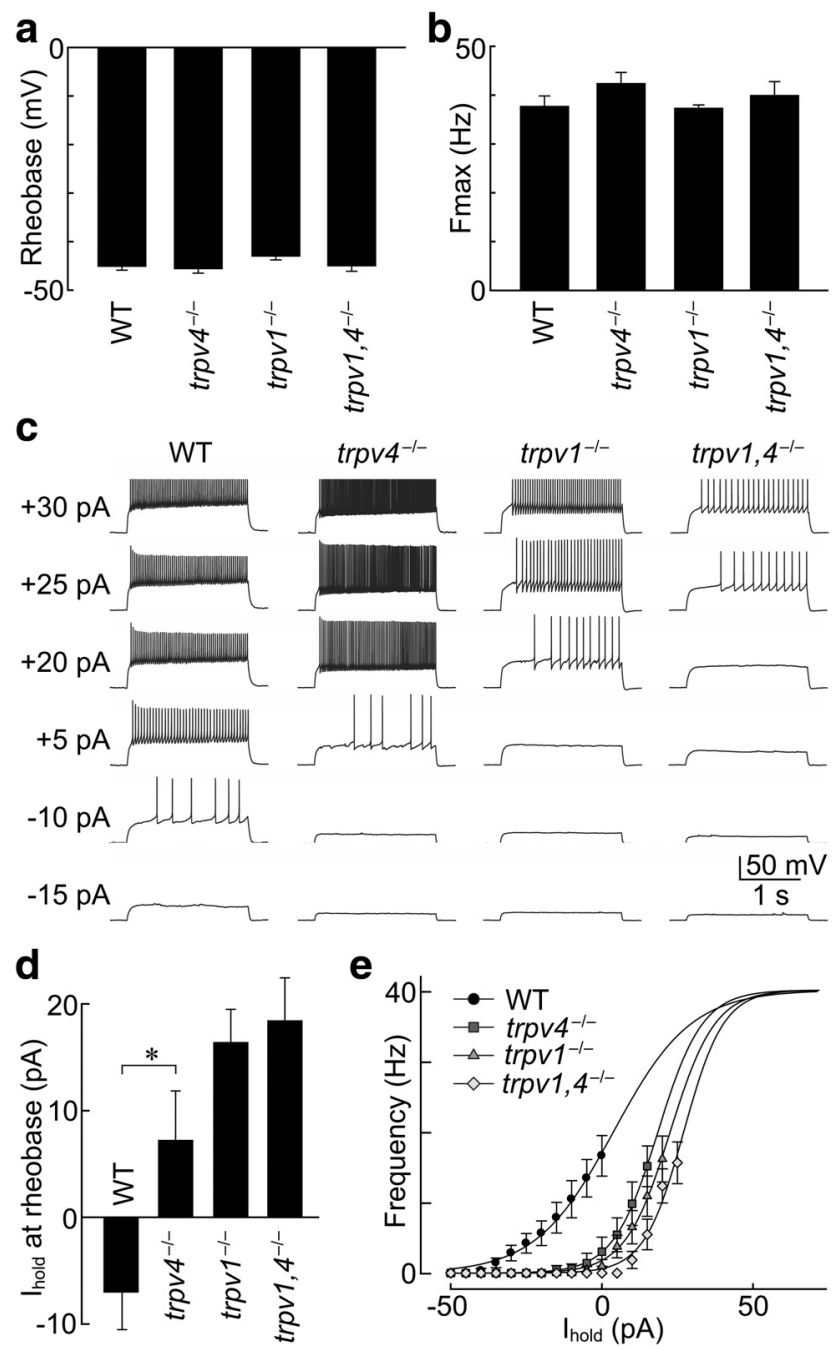

Figure 3. TRPV channels enhance excitability at Tb in MNCs. $\boldsymbol{a}, \boldsymbol{b}$, Error bars indicate mean \pm SEM values of rheobase $(\boldsymbol{a})$ and maximum firing frequency $\left(\mathrm{F}_{\text {max }}, \boldsymbol{b}\right)$ determined by current (I) injection during whole-cell current-clamp experiments in slices from mice of various genotypes. c, Traces show the effects of I (indicated on the left) on action potential firing in MNCs from different genotypes. $\boldsymbol{d}$, Error bars indicate mean \pm SEM holding I required to achieve rheobase (steady-state voltage at which firing first appears). ${ }^{*} p<0.05$. $\boldsymbol{e}$, Plots of steady-state firing frequency $(F)$ induced by I in MNCs of different genotypes. The solid lines are fits of the data using the equation: $\mathrm{F}=\mathrm{F}_{\max } /\left(1+\left[\mathrm{e}^{-(I-k) / s}\right]\right)$, where $\mathrm{s}$ is the slope factor and $k$ is the value of I at half-maximum.

$\operatorname{trp} v 4^{-1-}$ animals was not significantly different from WT $\left(\mathrm{T}_{\mathrm{C}}=1.15 \pm 0.33 \mathrm{~Hz} /{ }^{\circ} \mathrm{C} ; n=10, p=0.654\right.$; Fig. $\left.4 c\right)$.

To control for possible developmental compensatory changes associated with the loss of $\operatorname{trp} v 1$ or $\operatorname{trp} v 4$ expression in knock-out animals, we performed acute loss-of-function experiments using selective pharmacological inhibition of these channels in WT preparations. As illustrated in Figure $4 d$, the mean $\mathrm{T}_{\mathrm{C}}$ of WT MNCs was significantly reduced by bath application of SB$366791\left(\mathrm{~T}_{\mathrm{C}}=0.13 \pm 0.16 \mathrm{~Hz} /{ }^{\circ} \mathrm{C} ; n=7 ; p<0.0001\right)$, but not by the TRPV4 inhibitor HC-067047 $\left(\mathrm{T}_{\mathrm{C}}=0.95 \pm 0.20 \mathrm{~Hz} /{ }^{\circ} \mathrm{C} ; n=\right.$ $11 ; p=0.186)$.

\section{Discussion}

A previous study showed that temperature ramps rising $>35^{\circ} \mathrm{C}$ evoke proportional increases in inward current or firing rate in acutely isolated MNCs under voltage-clamp or current-clamp, respectively (Sharif-Naeini et al., 2008a). However, that study did a
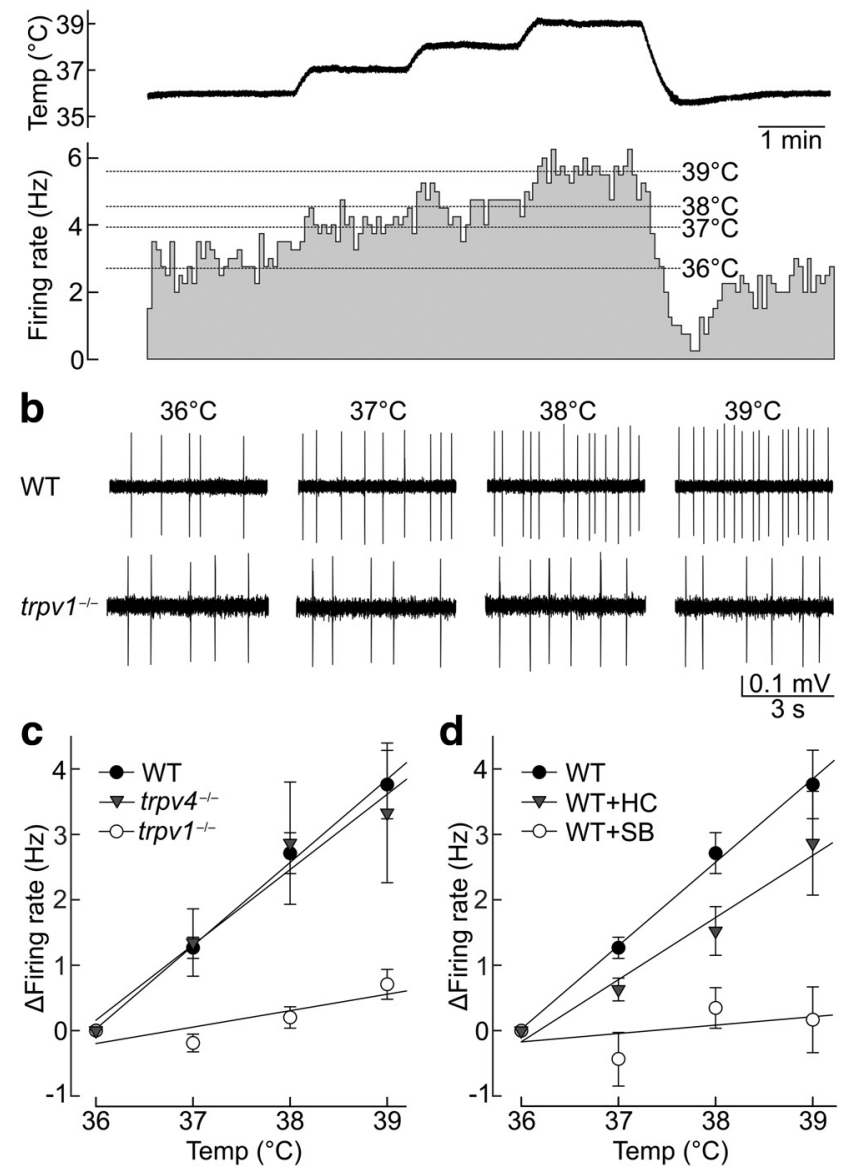

Figure 4. Dynamic role of TRPV1 but not TRPV4 in temperature sensing at Tb. $\boldsymbol{a}$, Plots represent the effect of changing ACSF temperature (temperature, top) on the firing rate of a WT MNC (bottom; bin width $4 \mathrm{~s}$ ). The steady-state frequency (dashed lines) achieved at each temperature was determined from the last minute of recording at each level. $\boldsymbol{b}$, Segments of steadystate single-unit activity recorded at different temperatures for the WT cell in (a) (top) and for a trpv1 ${ }^{-1-}$ cell (bottom). c, Plots represent mean \pm SEM changes in steady-state firing frequency ( $\Delta$ Firing rate) caused by changes in temperature for WT, trpv $4^{-1-}$, and trpv $1^{-1-}$ cells. $\boldsymbol{d}$, Plots represent temperature-induced $\Delta$ Firing rate for WT neurons under control conditions, or when exposed to SB-366791 (SB, $3 \mu \mathrm{m}$ ) or HC-067047 (HC, $1 \mu \mathrm{m})$. Solid lines indicate linear regressions through the data points.

not establish whether (or to what extent) TRPV1 channels contribute to heat-induced changes in firing rate, or whether heatinduced changes in firing can be maintained during prolonged changes in temperature, as occurs under physiological conditions. Notably, the same study revealed the existence of a sustained and RR-sensitive thermally activated current in trpv1 $1^{-/-}$ MNCs at Tb, suggesting that another channel might participate in heat detection in these cells. Because supraoptic nucleus MNCs express both TRPV1 and TRPV4 (Nedungadi et al., 2012), we sought to define the individual contributions of these two types of channels to physiological thermosensing in MNCs.

Our findings reveal that the basal spontaneous electrical activity of MNCs near Tb is significantly reduced by pharmacological blockade of either TRPV1 or TRPV4 channels. Indeed, MNCs lacking expression of either trpv1 or trpv4 were also found to be significantly hyperpolarized and less responsive to depolarizing current injection under steady-state conditions at $37^{\circ} \mathrm{C}$. Based on these observations, we conclude that TRPV1 and TRPV4 channels can both play a permissive role in thermosensation by MNCs. Specifically, the persistent cation 
current fluxing through these channels at $37^{\circ} \mathrm{C}$ serves to maintain RMP near rheobase, thus contributing to the discharge of spontaneous action potentials under resting conditions. This contribution is deemed permissive for thermosensation because it allows bidirectional changes in firing rate to occur when small changes in cation flux are induced by the temperature-dependent modulation of channel activity.

To determine whether TRPV1 and TRPV4 channels can both contribute to nonadapting dynamic thermosensation, we examined the effects of prolonged and physiologically relevant temperature steps on the steady-state firing rate of supraoptic MNCs. As expected, pharmacological blockade or genetic deletion of TRPV4 channels made it more difficult to detect spontaneously active MNCs during extracellular single-unit recording. For example, application of HC-067047 caused a significant decrease in the density of spontaneously active MNCs detected while advancing the microelectrode at $\mathrm{Tb}$ $(0.4 \pm 0.10$ active cells $/ 100 \mu \mathrm{m}$ in control, $n=10 ; 0.12 \pm 0.06$ in $\mathrm{HC}, n=16 ; p=0.015)$. However, the spontaneously active neurons that were detected under these conditions displayed temperature-dependent changes in firing rate that were equivalent to those observed in WT controls. By contrast, blockade or genetic deletion of TRPV1 channels caused a significant and profound reduction in the proportional thermal modulation of action potential firing rate observed $>36^{\circ} \mathrm{C}$ in spontaneously active MNCs. These findings suggest that the steadystate thermal activation of TRPV4 channels reaches an apparent maximum at a temperature near or $<36^{\circ} \mathrm{C}$, limiting the contribution of these channels to a permissive role under physiological conditions. In contrast, the proportional activation of channels encoded by the trpv1 gene extends well beyond $\mathrm{Tb}$ and is necessary to mediate the dynamic steady-state changes in firing that encode physiologically relevant temperature fluctuations between $36^{\circ} \mathrm{C}$ and $39^{\circ} \mathrm{C}$.

In contrast to those located in the brain, which detect small deviations in temperature near $\mathrm{Tb}$, thermosensory neurons located in the periphery must be capable of detecting and encoding an array of temperatures that ranges from nociceptive cooling $\left(<15^{\circ} \mathrm{C}\right)$ to nociceptive heating $\left(>40^{\circ} \mathrm{C}\right)$ (Foulkes and Wood, 2007; Zhu and Lu, 2010). Recent studies have suggested that this wide spectrum of sensitivity is achieved through the participation of distinct types of channels that are each sensitive to narrow yet overlapping ranges in temperature (Dhaka et al., 2006). In striking contrast, MNCs are rarely if ever exposed to temperatures breaching the $35-40^{\circ} \mathrm{C}$ range (Kiyatkin, 2007; Rango et al., 2012). The nonadapting and precise detection of small changes in Tb by these neurons is essential for the maintenance of osmotic homeostasis (Sharif-Naeini et al., 2008a; Sudbury et al., 2010). Our results indicate that channels encoded by $\operatorname{trp} v 1$ are the principal mediators of dynamic thermal sensing in supraoptic MNCs. It will be interesting to determine whether other types of central thermosensory neurons use a similar mechanism for heat detection and whether variations in core body temperature associated with fever-induced changes in set-point are associated with a modulation of the density or sensitivity of permissive TRPV4 channels, or dynamic TRPV1 channels. Finally, previous work has shown that supraoptic neurons do not express the full-length protein encoded by the trpv1 gene, but a variant lacking part of the channel's N-terminal cytoplasmic region (Sharif Naeini et al., 2006). Although it is the C-terminal region of the full-length TRPV1 protein that is required for thermosensation (Vlachová et al., 2003; Brauchi et al., 2006; Valente et al., 2008), it will be important to determine whether the variant expressed in su- praoptic MNCs displays specific properties that somehow enhance its role as a thermosensory transducer.

\section{References}

Boulant JA (1998) Hypothalamic neurons: mechanisms of sensitivity to temperature. Ann N Y Acad Sci 856:108-115. CrossRef Medline

Boulant JA (2000) Role of the preoptic-anterior hypothalamus in thermoregulation and fever. Clin Infect Dis 31 [Suppl 5]:S157-S161. CrossRef Medline

Brauchi S, Orta G, Salazar M, Rosenmann E, Latorre R (2006) A hot-sensing cold receptor: C-terminal domain determines thermosensation in transient receptor potential channels. J Neurosci 26:4835-4840. CrossRef Medline

Cabanac M (1975) Temperature regulation. Annu Rev Physiol 37:415-439. CrossRef Medline

Carreño FR, Ji LL, Cunningham JT (2009) Altered central TRPV4 expression and lipid raft association related to inappropriate vasopressin secretion in cirrhotic rats. Am J Physiol Regul Integr Comp Physiol 296:R454-R466. CrossRef Medline

Caterina MJ (2007) Transient receptor potential ion channels as participants in thermosensation and thermoregulation. Am J Physiol Regul Integr Comp Physiol 292:R64-R76. CrossRef Medline

Caterina MJ, Leffler A, Malmberg AB, Martin WJ, Trafton J, Petersen-Zeitz KR, Koltzenburg M, Basbaum AI, Julius D (2000) Impaired nociception and pain sensation in mice lacking the capsaicin receptor. Science 288: 306-313. CrossRef Medline

Davis JB, Gray J, Gunthorpe MJ, Hatcher JP, Davey PT, Overend P, Harries MH, Latcham J, Clapham C, Atkinson K, Hughes SA, Rance K, Grau E, Harper AJ, Pugh PL, Rogers DC, Bingham S, Randall A, Sheardown SA (2000) Vanilloid receptor-1 is essential for inflammatory thermal hyperalgesia. Nature 405:183-187. CrossRef Medline

Dhaka A, Viswanath V, Patapoutian A (2006) Trp ion channels and temperature sensation. Annu Rev Neurosci 29:135-161. CrossRef Medline

Everaerts W, Zhen X, Ghosh D, Vriens J, Gevaert T, Gilbert JP, Hayward NJ, McNamara CR, Xue F, Moran MM, Strassmaier T, Uykal E, Owsianik G, Vennekens R, De Ridder D, Nilius B, Fanger CM, Voets T (2010) Inhibition of the cation channel TRPV4 improves bladder function in mice and rats with cyclophosphamide-induced cystitis. Proc Natl Acad Sci U S A 107:19084-19089. CrossRef Medline

Forsling ML, Ingram DL, Stanier MW (1976) Effects of various ambient temperatures and of heating and cooling the hypothalamus and cervical spinal cord on antidiuretic hormone secretion and urinary osmolality in pigs. J Physiol 257:673-686. Medline

Foulkes T, Wood JN (2007) Mechanisms of cold pain. Channels (Austin) 1:154-160. Medline

Garami A, Pakai E, Oliveira DL, Steiner AA, Wanner SP, Almeida MC, Lesnikov VA, Gavva NR, Romanovsky AA (2011) Thermoregulatory phenotype of the Trpvl knockout mouse: thermoeffector dysbalance with hyperkinesis. J Neurosci 31:1721-1733. CrossRef Medline

Güler AD, Lee H, Iida T, Shimizu I, Tominaga M, Caterina M (2002) Heatevoked activation of the ion channel, TRPV4. J Neurosci 22:6408-6414. Medline

Hammel HT (1968) Regulation of internal body temperature. Annu Rev Physiol 30:641-710. CrossRef Medline

Hollis JH, McKinley MJ, D’Souza M, Kampe J, Oldfield BJ (2008) The trajectory of sensory pathways from the lamina terminalis to the insular and cingulate cortex: a neuroanatomical framework for the generation of thirst. Am J Physiol Regul Integr Comp Physiol 294:R1390-R1401. CrossRef Medline

Kauer JA, Gibson HE (2009) Hot flash: TRPV channels in the brain. Trends Neurosci 32:215-224. CrossRef Medline

Kim JA, Connors BW (2012) High temperatures alter physiological properties of pyramidal cells and inhibitory interneurons in hippocampus. Front Cell Neurosci 6:27. CrossRef Medline

Kiyatkin EA (2007) Physiological and pathological brain hyperthermia. Prog Brain Res 162:219-243. CrossRef Medline

Lee H, Iida T, Mizuno A, Suzuki M, Caterina MJ (2005) Altered thermal selection behavior in mice lacking transient receptor potential vanilloid 4 . J Neurosci 25:1304-1310. CrossRef Medline

Liedtke W, Friedman JM (2003) Abnormal osmotic regulation in trpv4 $4^{-1-}$ mice. Proc Natl Acad Sci U S A 100:13698-13703. CrossRef Medline Liedtke W, Choe Y, Martí-Renom MA, Bell AM, Denis CS, Sali A, Hudspeth 
AJ, Friedman JM, Heller S (2000) Vanilloid receptor-related osmotically activated channel (VR-OAC), a candidate vertebrate osmoreceptor. Cell 103:525-535. CrossRef Medline

Liedtke W, Tobin DM, Bargmann CI, Friedman JM (2003) Mammalian TRPV4 (VR-OAC) directs behavioral responses to osmotic and mechanical stimuli in Caenorhabditis elegans. Proc Natl Acad Sci U S A 100 [Suppl 2]:14531-14536.

McGaraughty S, Segreti JA, Fryer RM, Brown BS, Faltynek CR, Kym PR (2009) Antagonism of TRPV1 receptors indirectly modulates activity of thermoregulatory neurons in the medial preoptic area of rats. Brain Res 1268:58-67. CrossRef Medline

Moqrich A, Hwang SW, Earley TJ, Petrus MJ, Murray AN, Spencer KS, Andahazy M, Story GM, Patapoutian A (2005) Impaired thermosensation in mice lacking TRPV3, a heat and camphor sensor in the skin. Science 307:1468-1472. CrossRef Medline

Nedungadi TP, Carreño FR, Walch JD, Bathina CS, Cunningham JT (2012) Region-specific changes in transient receptor potential vanilloid channel expression in the vasopressin magnocellular system in hepatic cirrhosisinduced hyponatraemia. J Neuroendocrinol 24:642-652. CrossRef Medline

Patapoutian A, Peier AM, Story GM, Viswanath V (2003) ThermoTRP channels and beyond: mechanisms of temperature sensation. Nat Rev Neurosci 4:529-539. CrossRef Medline

Ramsey IS, Delling M, Clapham DE (2006) An introduction to TRP channels. Annu Rev Physiol 68:619-647. CrossRef Medline

Rango M, Arighi A, Bresolin N (2012) Brain temperature: what do we know? Neuroreport 23:483-487. CrossRef Medline

Romanovsky AA (2007) Thermoregulation: some concepts have changed. Functional architecture of the thermoregulatory system. Am J Physiol Regul Integr Comp Physiol 292:R37-R46. CrossRef Medline

Sharif Naeini R, Witty MF, Séguéla P, Bourque CW (2006) An N-terminal variant of Trpv1 channel is required for osmosensory transduction. Nat Neurosci 9:93-98. CrossRef Medline

Sharif-Naeini R, Ciura S, Bourque CW (2008a) TRPV1 gene required for thermosensory transduction and anticipatory secretion from vasopressin neurons during hyperthermia. Neuron 58:179-185. CrossRef Medline
Sharif-Naeini R, Ciura S, Stachniak TJ, Trudel E, Bourque CW (2008b) Neurophysiology of supraoptic neurons in C57/BL mice studied in three acute in vitro preparations. Prog Brain Res 170:229-242. CrossRef Medline

Shibasaki K, Suzuki M, Mizuno A, Tominaga M (2007) Effects of body temperature on neural activity in the hippocampus: regulation of resting membrane potentials by transient receptor potential vanilloid 4 . J Neurosci 27:1566-1575. CrossRef Medline

Sudbury JR, Ciura S, Sharif-Naeini R, Bourque CW (2010) Osmotic and thermal control of magnocellular neurosecretory neurons: role of an N-terminal variant of trpv1. Eur J Neurosci 32:2022-2030. CrossRef Medline

Todaka H, Taniguchi J, Satoh J, Mizuno A, Suzuki M (2004) Warm temperature-sensitive transient receptor potential vanilloid 4 (TRPV4) plays an essential role in thermal hyperalgesia. J Biol Chem 279:3513335138. CrossRef Medline

Trudel E, Bourque CW (2003) A rat brain slice preserving synaptic connections between neurons of the suprachiasmatic nucleus, organum vasculosum lamina terminalis and supraoptic nucleus. J Neurosci Methods 128:67-77. CrossRef Medline

Valente P, García-Sanz N, Gomis A, Fernández-Carvajal A, FernándezBallester G, Viana F, Belmonte C, Ferrer-Montiel A (2008) Identification of molecular determinants of channel gating in the transient receptor potential box of vanilloid receptor I. FASEB J 22:3298-3309. CrossRef Medline

Vasilenko V, Beliavskiı̌ EM, Gurin VN (1989) [Temperature dependence of neuronal activity in hypothalamic and hippocampal slices of the guineapig]. Neirofiziologiia 21:358-365. Medline

Vlachová V, Teisinger J, Susánková K, Lyfenko A, Ettrich R, Vyklický L (2003) Functional role of C-terminal cytoplasmic tail of rat vanilloid receptor 1. J Neurosci 23:1340-1350. Medline

Zhu YJ, Lu TJ (2010) A multi-scale view of skin thermal pain: from nociception to pain sensation. Philos Tran A Math Phys Eng Sci 368:521-559. CrossRef Medline 